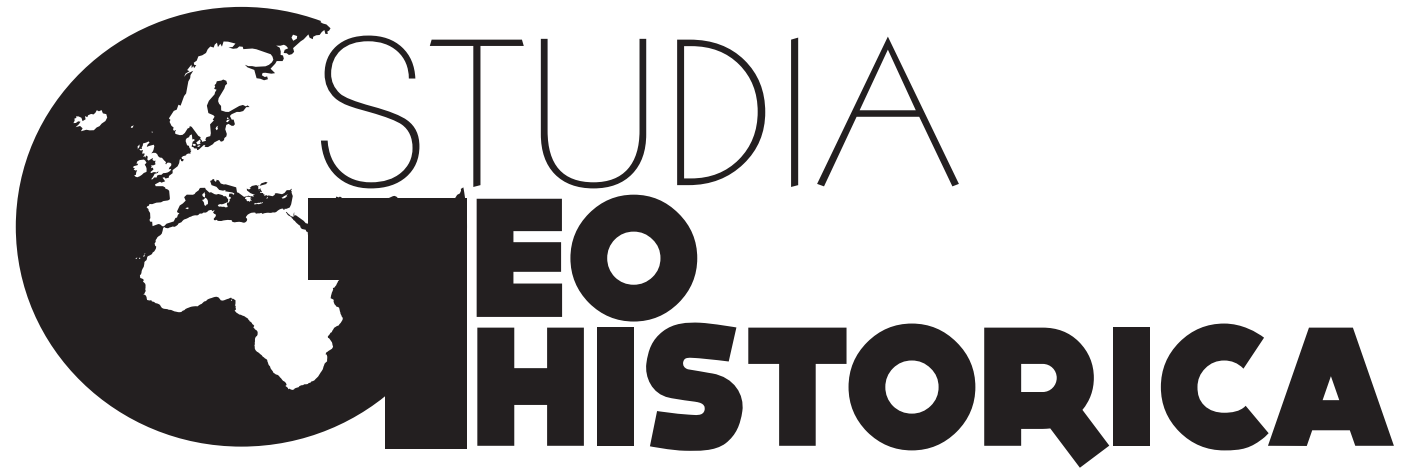

NR 04|2016 ROCZNIK HISTORYCZNO-GEOGRAFICZNY

Fundacja Centrum GeoHistorii • Instytut Geodezji i Kartografii • Instytut Historii KUL

Instytut Historii i Stosunków Międzynarodowych US • Zespół Historii Kartografii przy Instytucie Historii Nauki PAN Biblioteka Główna Uniwersytetu Szczecińskiego 


\section{STUDIA GEOHISTORICA. Rocznik historyczno-geograficzny}

\section{Redakcja}

Bogumił Szady (redaktor naczelny), Beata Konopska, Radosław Skrycki, Tomasz Związek (sekretarz redakcji), Tomasz Panecki

\section{Redakcja językowa i korekta}

Konrad Byzdra

\section{Tłumaczenia}

autorzy, Julia Szołtysek

\section{Rada Naukowa}

Zdzisław Budzyński (Rzeszów), Andrzej Janeczek (Warszawa), Tomasz Jurek (Poznań), Keith Lilley (Belfast/Wielka Brytania), Andrew Pernal (Brandon/Kanada), Tadeusz Siwek (Ostrawa/Czechy), Rostysław Sossa (Kijów/Ukraina), Grzegorz Strauchold (Wrocław), Robert Šimůnek (Praga/Czechy)

\section{Recenzenci tomu 4}

Wojciech Chudziak, Martyna Deszczyńska, Zbigniew Górczak, Maria Jankowska, Iwona Jażdżewska, Andrzej Klonder, Anna Kołodziejczyk, Andrzej Kopiczko, Małgorzata Elżbieta Kowalczyk, Adam Kozak, Joanna Kumor-Mielnik, Mieczysław Kunz, Dariusz Lorek, Wojciech Mielewczyk, Grzegorz Myśliwski, Wiesław Nowosad, Piotr Pabjanek, Marek Radoch,

Małgorzata Rutkiewicz-Hanczewska, Francesco Somaini, Péter Szabó, Piotr Werner, Filip Wolański

\section{Redakcja map}

autorzy, Tomasz Panecki

\section{Adres Redakcji}

Fundacja Centrum GeoHistorii

Redakcja Studia Geohistorica

05-082 Stare Babice, ul. Gen. Tadeusza Kutrzeby 4

\section{Strona internetowa}

studiageohistorica.pl

Wersja drukowana (papierowa) jest wersją pierwotną rocznika Studia Geohistorica

\section{Współwydawcy rocznika}

Biblioteka Główna Uniwersytetu Szczecińskiego, Fundacja Centrum GeoHistorii, Instytut Geodezji i Kartografiii, Instytut Historii Katolickiego Uniwersytetu Lubelskiego Jana Pawła II, Instytut Historii i Stosunków Międzynarodowych Uniwersytetu Szczecińskiego, Zespół Historii Kartografii przy Instytucie Historii Nauki PAN

Rocznik wydawany pod patronatem Komisji Geografii Historycznej przy Polskim Towarzystwie Historycznym Projekt okładki: Jacek Młodożeniec Ilustracja na okładce: Kalisz - Plan miasta i przyległej okolicy autorstwa Ludwiga von Bröckera z 1802 r. Skład i łamanie: Artur Hamryszczak

(C) Copyright by Fundacja Centrum GeoHistorii

ISSN 2300-2875

Nakład 100 egz.

Warszawa 2016 


\section{Spis treści • Contents}

\section{Tradycje geografi historycznej • Traditions of historical geography}

\section{Ludomir Sawicki}

Geografia a krajoznawstwo

(uwagi wstępne Beata Konopska, opracowanie Beata Konopska)

\section{Stanisław Herbst}

Prace nad „Atlasem historycznym Polski”

(uwagi wstępne Henryk Rutkowski, opracowanie Henryk Rutkowski).

\section{Artykuty $\bullet$ Articles and theses}

\section{Elżbieta Kowalczyk-Heyman}

Czym były mazowieckie "płozy"? (uwagi wstępne)

What were the Masovian "płozy"? (Preliminary Remarks)

\section{Robert Klimek}

Ślady średniowiecznej granicy Warmii między Reszlem a Świętą Lipką

Traces of the Medieval Border of Warmia between Reszl and Święta Lipka

\section{Ewa Ziółek}

Relacja Grzegorza Piramowicza o osuszaniu Bagien Pontyjskich za pontyfikatu Piusa VI

Grzegorz Piramowicz's Account of Draining the Pontian Marshes during

the Pontificate of Pope Pius VI

\section{Krzysztof Boroda}

Wpływy z czopowego jako wskaźnik lokalnego zróżnicowania poziomu produkcji

piwa pełnego w miastach Królestwa Polskiego w latach 60. XVI w.

Income from Czopowe as an Indicator of Regional Diversity of Full Beer

Production in the Cities of the Polish Crown in the 1560s

\section{Xavier Rochel}

The End of Gaps and Heathlands in French National Forests, $19^{\text {th }}$ Century.

A Case Study Based on Forest Management Plans

Zanik polan i wrzosowisk we francuskich lasach państwowych w XIX w.

Studium przypadku na podstawie planów zarządzania lasami

\section{Tomasz Figlus}

Typy morfogenetyczne wsi w środkowej Polsce

Morphogenetic Types of Rural Settlements in Central Poland. 
Tomasz Babczyński, Tomasz Kubik, Roman Ptak, Grzegorz Strauchold GIS as a Tool to Analyze the History of Silesia and the Changes in its Political (and Cultural) Geography GIS jako narzędzie do analizy historii Śląska oraz zmian w jego geografii politycznej i kulturowej..

\section{Mateusz Zawadzki}

"Tabella miast, wsi i osad Królestwa Polskiego" jako źródło do badań nad strukturą parafialną województwa lubelskiego

The "Tabella of Towns, Villages and Settlements of the Kingdom of Poland" as the Source for Research into the Parochial Structure of the Lublin Voivodeship

Anna Paulina Orłowska, Bartosz Nowożycki, Grzegorz Pac Handel wołami na terenie Wielkopolski i Śląska w świetle szesnastowiecznego spisu jarmarków i komór celnych The Trade in Oxen on the Territory of the Greater Poland and Silesia in the Light of the $16^{\text {th }}$ Century Description of Annual Fairs and Toll Houses

\section{Recenzje i omówienia $・$ Reviews and discussions}

Historical Atlas of Poland in the $2^{\text {nd }}$ half of the $16^{\text {th }}$ Century: Voivodeships of Cracow, Sandomierz, Lublin, Sieradz, Łęczyca, Rawa, Płock and Mazovia, ed. by Marek Słoń; transl. by Agata Staszewska; Martha A. Brożyna, Peter Lang Edition, Frankfurt am Main 1973-[2014], 4 volumes, XXIX + 1597 pp., illustrations, 27 folded maps

(Alexei Frolov)

Magdolna Szilágyi: On the Road: The History and Archaeology of Medieval Communication Networks in East-Central Europe, Budapest 2014

(Archeolingua Series Minor, 35),

Ss. 254, 89 il. (w tym 30 map i 4 plany miast)

(Ewelina Siemianowska).

The World in a Mirror, Word Maps from the Middle Ages to the Present Day, ed. Jan Parmentier, Museum aan de Stroom, Antwerp 2015, ss. 192, il. $150+25$ (Lucyna Szaniawska)

Kartografia morska i krain nadmorskich, red. R. Skrycki, Instytut Historii

i Stosunków Międzynarodowych Uniwersytetu Szczecińskiego,

Zespół Historii Kartografii Instytutu Historii Nauki PAN, Szczecin 2014;

$24 \times 17$ cm, ss. 204, 54 ryc., 4 tab.

(Jan Rutkowski) 
Алексей А. Фролов, Нина В. Пиотух: Исторический атлас Деревской пятины Новгородской земли (по писцовым книгам письма 1495-1496 годов). В 3 томах: Москва-Санкт-Петербург, Альянс-Архео, 2008.

Т. 1: Исследование и таблицы, ss. 368;

Т. 2: Атлас и справочные материалы, ss. 272;

T. 3: Уездные планы последней четверти XVIII века, ss. 266

(Rostysław Sossa).

Nazwy miejscowe Polski. Historia. Pochodzenie. Zmiany, t. 10-12 (Ra-Rż), red. K. Rymut, B. Czopek-Kopciuch, U. Bijak, [autorzy haseł: U. Bijak, E. Borysiak, J. Chłądzyńska, B. Czopek-Kopciuch, P. Dudek, A. Galasińska, W. Makula-Kosek, I. Nobis, R. Przybytek, P. Swoboda, U. Wójcik, K. Zawodzińska-Bukowiec, Z. Zierhoffer], Polska Akademia Nauk. Instytut Języka Polskiego, Kraków 2015, ss. 160 (t. 10), 146 (t. 11), 168 (t. 12) (Ewa Oronowicz-Kida).

Kit Mayers: The First English Explorer. The Life of Anthony Jenkinson (1529-1611) and his Adventures on Route to the Orient, Devon 2015, ss. 366

(Krystyna Szykuła).

\section{Komunikaty $i$ sprawozdania $\bullet$ Communiques and reports}

Konferencja „Przestrzenne aspekty historycznych badań demograficznych, społecznych i gospodarczych (do 1945 r.)" - Pobierowo, 21-23 października 2015 r.

(Michał Gochna)

„European Social Science History Conference” - Walencja (Hiszpania),

30 marca-2 kwietnia $2016 \mathrm{r}$.

(Michał Gochna)

Zebranie naukowe polskiej sekcji European Society for Environmental History - Warszawa, 16 stycznia $2016 \mathrm{r}$.

(Piotr Guzowski)

„Mapa jako narracja interpretacyjna”. XXIX Ogólnopolska Konferencja Historyków Kartografii - Wrocław, 24-26 września $2015 \mathrm{r}$.

(Jerzy Ostrowski)

Sprawozdanie z konferencji „Województwo poznańskie w XVI w.” - Kościan, 1 lipca 2015 r.

(Michał Stomski).

Sprawozdanie z konferencji „Geografia historyczna. Wyzwania przyszłości” - Łódź, 11-12 czerwca 2015 r.

(Magdalena Deptuła). 204 
Spis treśsi

Pro memoria

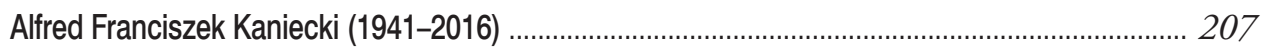

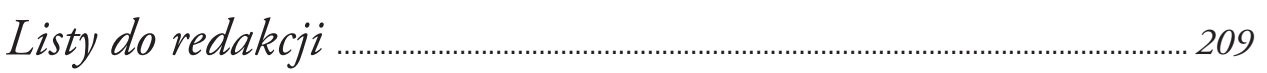

Informacja dla autorów • Guidelines for Authors .................................................... 210 


\title{
Handel wołami na terenie Wielkopolski i Śląska w świetle szesnastowiecznego spisu jarmarków i komór celnych
}

\author{
Anna Paulina Orłowska, Bartosz Nowożycki, Grzegorz Pac
}

Przedmiotem niniejszego tekstu jest nieopublikowane dotąd Spisanie jarmarków wielgopolskich, to jest przed granicami sliaskiemi, także i $w$ Sliasku, w miastach cesarskich i ksiażęcych, na których trzeba bywajać pilności wielki. Przechowywany w Archiwum Głównym Akt Dawnych poszyt mimo niezbyt dużej objętości wnosi nowe informacje zarówno na temat funkcjonowania sieci jarmarcznej w Wielkopolsce i na Śląsku, jak i w kwestii handlu wołami na tym terenie. Opatrzyliśmy tę edycję poszerzonym wstępem rzeczowym oraz wstępem edytorskim. Z charakteru wprowadzenia rzeczowego wynikają pewne ograniczenia chronologiczne i merytoryczne. Ponieważ źródło powstało w XVI w., tekst koncentruje się na tym okresie, bez szczegółowej analizy wcześniejszych przemian, których wynikiem są omawiane fakty ${ }^{1}$. Zrezygnowaliśmy też z porównywania prezentowanego źródła $\mathrm{z}$ podobnymi tekstami z tego okresu.

Hodowla wołów i handel nimi był dla Rzeczypospolitej Obojga Narodów szczególnie ważną gałęzią gospodarki. Dobitnie ujął to Antoni Mączak, pisząc: „Dla regionów śródlądowych w XVI-XVII w. handel wołami odgrywał rolę analogiczną do morskiego handlu zbożem"2. Słuszność tego porównania leży nie tylko w wielkości obrotu handlowego, który obejmował kilkaset tysięcy zwierząt rocznie i gwarantował zaopatrzenie w mięso licznym miastom Europy

\footnotetext{
${ }^{1}$ Dla zrozumienia szerszego kontekstu szczególnie cenne są prace: J. Topolski, Rola Gniezna w handlu europejskim od XV do XVII wieku, "Studia i Materiały do Dziejów Wielkopolski i Pomorza", 7 (2), 1962, s. 5-78; H. Samsonowicz, Jarmarki w Polsce na tle sytuacji gospodarczej w Europie w XV-XVI wieku, w: Europa - Stowiańszczyzna - Polska. Studia ku uczczeniu profesora Kazimierza Tymienieckiego, wyd. J. Bardach i in., Poznań 1970, s. 523-532; tenże, Przemiany osi drożnych w Polsce późnego średniowiecza, „Przegląd Historyczny”, 64 (4), 1973, s. 697-716.

2 A. Mączak, Heinz Wiese, Johann Bölts, „Rinderhandel und Rinderhaltung im nordwesteuropäischen Küstengebiet vom 15. bis zum 19. Jahrhun-
}

Zachodniej, ale także w jego przyczynach. Gwałtowny wzrost liczby ludności na zachodzie kontynentu połączony ze wzrostem produkcji pozarolniczej zwiększył import produktów spożywczych z terenów Europy Wschodniej i Środkowo-Wschodniej. Mimo zbliżonych miejsc produkcji i tych samych miejsc zbytu drogi transportu obu towarów nie tylko nie były zbieżne, ale jedynie się przecinały. Rzeki, niezbędne w transporcie ciężkiego w stosunku do ceny zboża, dla handlu wołami stanowity przeszkodę. Stąd charakterystycznymi punktami na trasach handlu wołami, czyli towarem, który - jak słusznie zauważył Wolfgang von Stromer - sam transportuje się do celu, były brody na rzekach, a trasy przepędu zwierząt przebiegały na osi wschód-zachód, równolegle do Karpat ${ }^{3}$.

Niestety, ta ważna dziedzina handlu doczekała się w wypadku ziem polskich w zasadzie tylko jednego całościowego opracowania. Mamy tu na myśli pracę Jana Baszanowskiego pt. $Z$ dziejów handlu polskiego $w$ XVI-XVIII w. Handel wota$m i^{4}$. Podejmując tak rozległy temat, autor zastrzegał: „Praca nie rości sobie [...] pretensji do pełnego poruszenia i zamknięcia poruszonych zagadnień. Powinna za to przyczynić się do podjęcia dyskusji i zainicjowania badań szczegółowych, które mogą zresztą doprowadzić do uściślenia niektórych przedstawionych $\mathrm{w}$ niniejszej pracy poglądów i tez" ${ }^{\prime 5}$. Niestety od czasów ukazania się

dert”, „Quellen und Forschungen zur Agrargeschichte” herausgegeben von Friedrich Lütge, Günther Franz und Wilhelm Abel, t. XIV, Gustav Fischer Verlag. Stuttgart 1966, s. 272, „Przegląd Historyczny”, 60 (4), 1969 , s. 731-735.

3 W. von Stromer, Wildwest in Europa: Der transkontinentale Ochsenhandel in der frühen Neuzeit, „Kultur und Technik”, 2, 1979, s. 36-43.

4 J. Baszanowski, Z dziejów handlu polskiego w XVI-XVIII w. Handel wotami, Gdańsk 1977.

5 Tamże, s. 8. 
tej publikacji badania poświęcone kwestii wołów, ich hodowli i handlowania nimi nie posunęty się znacząco. Częściowo jest to rezultat trudności wynikających z charakteru bazy źródłowej, którą Baszanowski uważał za szczupłą i rozproszoną, a ponadto pozbawioną materiałów statystycznych dla XVII-XVIII w., jak „księgi celne, uwzględniające wywóz wołów, z których dla okresu wcześniejszego korzystał Roman Rybar-

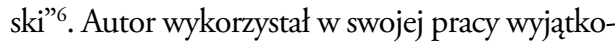
wo szerokie spektrum źródeł: lustracje, inwentarze, rewizje, Metrykę Koronną, konstytucje sejmowe, mandaty i dekrety władców i urzędników, księgi grodzkie, ziemskie, niektóre księgi miejskie, rachunki skarbowe, księgi rekognicji, przekazy publicystyczno-kronikarsko-pamiętnikarskie, instruktarze czy wreszcie podręczniki gospodarskie. Jednocześnie zwracał uwagę na niewykorzystany materiał, jakim są księgi miejskie i archiwa prywatne, przewidując zarazem, że zasoby te nie zostaną zbadane ze względu na ich obszerność, tym bardziej że wzmianki na temat wołów nie są w nich zbyt częste ${ }^{7}$. Przewidywał, że większe opracowania tematu pojawią się po odnalezieniu nowych, zwartych archiwaliów, podobnych do tych, na których opierał się w swej pracy Roman Rybarski ${ }^{8}$.

Niemniej jednak praca Jana Baszanowskiego przynosi wiele cennych ustaleń. Zrekonstruował on szlak, którym w XVI w. przepędzano bydło $\mathrm{z}$ miejsc hodowli do odbiorców. Zaczynał się on w Mołdawii, na jarmarkach w Suczawie, Bakowie, Romanie, Banii i Niemcu, a od drugiej połowy XVI w. - w Botoszanach, Łenkowicach i Szypienicy. Biegł przez Ruś Czerwoną i Podole i dalej, idąc na zachód i północny-zachód, przemierzał Małopolskę i Wielkopolskę i kończył się albo w Gdańsku, albo poza granicami kraju, na wielkich jarmarkach śląskich i niemieckich, gdzie zaopatrywali się zazwyczaj docelowi odbiorcy. Obszar Wielkopolski i Śląska był więc ostatnim miejscem, gdzie lokalni kupcy mogli się włączyć w dalekosiężny handel wołami. Jako że tu właśnie

\footnotetext{
${ }^{6}$ Tamże, s. 11.

${ }^{7}$ Tamìe, s. 12-13.

${ }^{8}$ Tamże, s. 8.

${ }^{9}$ Tamże, s. 173
}

zwierzęta opuszczały polskie granice, tereny te były również szczególnie ważne dla oceny skali międzynarodowego handlu bydłem, co znajduje swoje odzwierciedlenie zarówno w prezentowanym źródle, jak i we współczesnych badaniach.

Opisany powyżej szlak handlu wołami jest bardzo uproszczony, jednak doprecyzować można go tylko w ograniczonym stopniu. W polskiej historiografii nie tylko nie ma zgody co do przebiegu poszczególnych dróg, ale wręcz podawane jest w wątpliwość samo istnienie oddzielnych szlaków przepędu bydła. Baszanowski pisał o nich: „Wiodły więc te szlaki tymi samymi drogami i nie miały żadnego specjalnego charakteru" . Dystansuje się tym samym wobec opinii Mariana Wolańskiego, który mówił o szlakach wołowych: „Specjalny charakter posiadały zwyczajne, często nieokopane rowami drogi przechodzące przez Małopolskę" ${ }^{10}$. Nowsza historiografia ponownie przychyla się do zdania Mariana Wolańskiego. Henryk Bartoszewicz, odtwarzając drogi handlowe ziemi chełmińskiej, zwrócił uwagę na tak podstawowe fakty, jak konieczność zapewnienia stadom popoju i wypasu oraz destruktywny wpływ dużych stad zwierząt na infrastrukturę drogową, np. niszczone w wyniku ich przejścia koleiny. Dlatego przyjmuje on, że przepęd bydła czy koni po drogach przeznaczonych do transportu kołowego możliwy był tylko na krótkich odcinkach i przy niewielkiej liczebności stad. Do masowego transportu potrzebne były inne drogi: szersze, pozbawione części zbędnej infrastruktury, o przebiegu przewidującym potrzeby fizjologiczne zwierząt. Uwzględniając pobieranie cła tylko od pędzonego bydła oraz inne źródła, przyjmuje on, że w XIV-XVI w. istniały - przynajmniej w ziemi chełmińskiej - drogi, „na których jeśli nie jedynym, to z pewnością dominującym rodzajem ruchu był przepęd bydła i koni" ${ }^{\prime 1}$. Należy jednak pamiętać, że wyznaczona droga mogła się zmieniać, nawet w ciaggu jednego roku, np. w wyniku zerwania grobli czy protestów właścicieli ziem, przez które przepę-

\footnotetext{
${ }^{10}$ M. Wolański, Związki handlowe Śląska z Rzecząpospolitą w XVII wieku, Wrocław 1961, s. 53

${ }^{11}$ H. Bartoszewicz, Drogi handlowe ziemi chetmińskiej, ,Miscellanea Historico-Archivistica", 6, 1996, s. 54.
} 
dzano zwierzęta. Skargi na te utrudnienia opisywały zazwyczaj szlak, którym pędzono bydło. Wraz z juramentami, przywilejami miast, lustracjami, taryfami celnymi i mytniczymi, edyktami królewskimi oraz ustawami sejmowymi umożliwiają dość szczegółowe nakreślenie dróg handlu wołami, z oczywistym zastrzeżeniem, że są to szlaki tylko najbardziej prawdopodobne, a droga pomiędzy poszczególnymi miejscowościami była dość dowolna - handlu wołowego nie obejmował bowiem ścisły przymus drogowy ${ }^{12}$.

Na podstawie tych źródeł Jan Baszanowski zrekonstruował dwa prawdopodobne szlaki przepędu bydła. Droga, którą nazwać można południową, prowadziła z Suczawy przez Kołomyję, Stanisławów, Halicz, Rohatyn, Bóbrkę, Lwów, Zimną Wodę, Stawczany, Gródek, Radytycze, Wisznię, Wojkowice, Mościska, Medykę, Przemyśl, Radymno, Tuczampy, Jarosław, Przeworsk, Trynczę, Leżajsk, Kopki, Trześń, Sandomierz, Chęciny, Małogoszcz, Lelów, Olsztyn i Częstochowę do Krzepic ${ }^{13}$. Droga północna wiodła natomiast z Kamieńca Podolskiego przez Skałę, Trembowlę, Pomorzany, Gołogóry, Busk, Kamionkę Strumiłowską, Bełz, Telatyn, Zamość, Tyszowce (lub Hrubieszów i Wojsławice), Krasnystaw, Lublin, Wąwolnicę, Kazimierz, Zwoleń, Linów, Radom, Przytyk, Opoczno, Radomsko, Brzeźnicę (lub Piotrków), Wieluń, Bolesławiec i dalej za granicę $e^{14}$. Baszanowski twierdzi, że początkowo szlak ten służył do przepędu stad z linii Bełz-Chełm, ale z czasem, od XVI w. zaczęto tamtędy pędzić również stada z Podola, a od XVII w. - także z Ukrainy. Dynamika szlaku wynika z przemian sieci jarmarków w Polsce wywołanych przez czynniki makroekonomiczne.

$\mathrm{Na}$ ile te fakty były znane handlarzom z Wielkopolski? Publikowane źródło niestety nie pozwala na jednoznaczną ocenę, podaje bowiem

\footnotetext{
12 J. Baszanowski, $Z$ dziejów, s. 90-91. Tę drogę rekonstruuje też na podstawie danych z czestochowskiej komory celnej Henryk Samsonowicz. H. Samsonowicz, Handel na pograniczu polsko-śląskim w świetle danych komory celnej w Częstochowie z 1584 r., „Kwartalnik Historyczny”, 99 (4), 1992, s. 16

${ }^{13}$ J. Baszanowski, Z dziejów, s. 95.

${ }^{14}$ Tamże, s. 97. Za granicami Polski woły trafialy głównie do odbiorców niemieckich. Rynki włoskie i częściowo francuskie zaopatrywane były za pomocą szlaków prowadzących po południowej stronie Karpat. W. von Stromer, Wildwest, s. 40.
}

jedynie ogólny kierunek handlu, zaznaczając, że woły idą z nadbużańskiego Sokala oraz z Podlasia. O świadomości poszerzenia geograficznego zaplecza hodowlanego handlu na drodze pótnocnej nie da się więc jednoznacznie wyrokować. W tekście nie ma uwag zalecających obserwację pochodzenia wołów, co może się wiązać $\mathrm{z}$ adresatem źródła. Fakt, że obszar obejmowany przez prezentowane źródło znajdował się w ostatniej części drogi północnej wraz z wielokrotnie występującym w tekście nakazem liczenia przechodzących wołów czy zwracania uwagi na kupujących, może sugerować, że adresatem źródła była osoba kontrolująca (na potrzeby państwa albo osoby prywatnej) handel wołami.

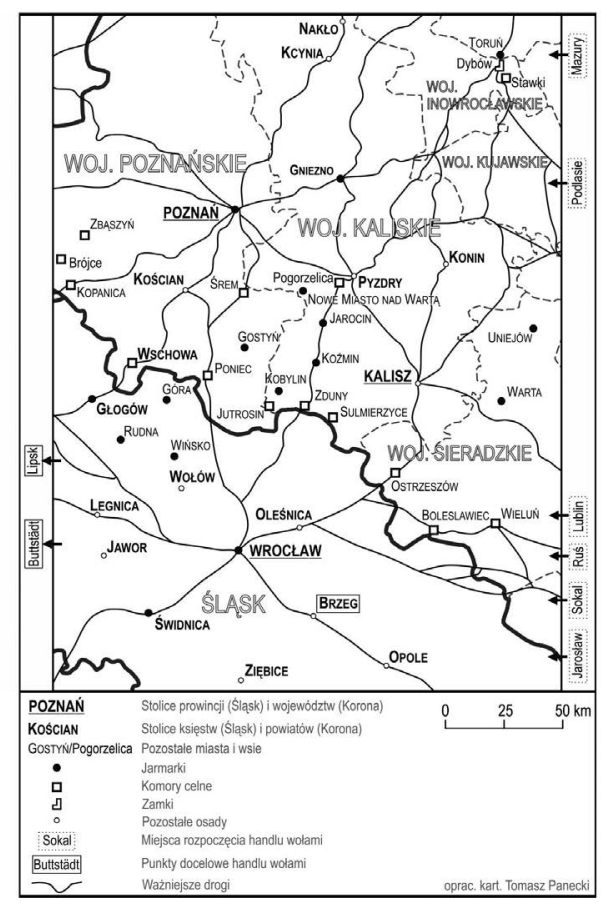

Mapa 1. Miejsca ważne dla handlu wołami w świetle „Spisania jarmarków"

Jak już wspominano, handlu wołami nie obowiązywał ścisły przymus drogowy, a urzędnicy królewscy dbali jedynie o to, by odprowadzane było należne cło. $Z$ biegiem czasu jednak coraz liczniejsza stawała się grupa, która dzięki przywilejom - imiennym lub dla wszystkich kupców $\mathrm{z}$ danego miasta - była zwolniona z uiszczania tej 
opłaty. Tym samym nawet przy szczelnym systemie komór celnych wpływy z cła były nieproporcjonalnie niskie w stosunku do skali handlu. W związku z tym, gdy Zygmunt I zasiadł na tronie w Polsce i szukał nowych źródeł zasilania skarbu, zdecydował się na wprowadzenie nowego cła na handel wołami. Zostało ono uchwalone przez sejm w 1507 r. $^{15}$ Jako eksportowe, pobierano je tylko na komorach granicznych, zaś na komorach wewnątrz kraju utrzymywało się stare cło ${ }^{16}$. Lakoniczność sejmowej konstytucji powodowała, że między badaczami istniał niegdyśs spór, czy nowe cło pobierano tylko w Małopolsce, czy też na terenie całego kraju. Już w dwudziestoleciu międzywojennym udało się jednak ustalić, że jego zasięg był ogólnokrajo$w^{17}$. Obejmowało wszystkie grupy społeczne i nie przewidywało zwolnień, dzięki czemu z jednej strony uniemożliwiało oszustwa celne polegające na wynajmowaniu do przeprowadzania stad osób zwolnionych z cła, z drugiej zaś rejestracja cła płaconego na komorach pogranicznych (a więc i liczby przechodzących wołów) dawała adekwatny obraz handlu bydłem.

Publikowane przez nas źródło może rzucić nowe światło na pobór cła od wołów. Jest ono zbliżone do opisywanego przez Rybarskiego Spisu jarmarków, na których trzeba bywać, który badacz ten datował na rok $1584 \mathrm{i}$ interpretował jako instrukcję dla pisarza lub strażnika celnego wielkopolskiego ${ }^{18}$. Adresatem niniejszego instruktarza była $\mathrm{z}$ pewnością osoba zainteresowana handlem wołami, a jednocześnie niezbyt doświadczona. Mógł to być początkujący kupiec, ale równie dobrze osoba pełniąca nadzór nad poborem podatków. Tekst opisuje bowiem nie tylko newralgiczne miejsca handlu wołami, ale też właściwy sposób zachowania określony jako „wielka pilność”, czyli zwiększona czujność oraz

\footnotetext{
${ }^{15}$ Volumina constitutionum, oprac. W. Uruszczak, S. Grodziski, I. Dwornicka, t. 1, vol. 1: 1493-1526, Warszawa 2000, s. 291-293.

${ }^{16}$ J. Baszanowski, $Z$ dziejów, s. 27.

${ }^{17}$ R. Rybarski, Handel i polityka handlowa Polski w XVI stuleciu, t. 1: Rozwój handlu polityki handlowej, Poznań 1928, s. 18.

${ }^{18}$ Tamże, s. 204.

${ }^{19}$ Tekst sprawia przy tym wrażenie, jakby autor odbierał te dwa tereny jako jedną przestrzeń gospodarczą, niezależnie od przebiegu granic państwowych.
}

liczenie, ile wołów zostanie dopuszczonych do paszy. Podobne w duchu zalecenia można odnaleźć w podręcznikach dla adeptów fachu kupieckiego spisywanych przez doświadczonych kupców. Kto i w jakim celu spisał wydawany przez nas tekst, pozostaje jednak niewiadome. Opis, w którym większość not rozpoczyna się od daty określanej nazwą święta kościelnego, ułożony jest chronologicznie i obejmuje okres od stycznia, a dokładniej od Objawienia Pańskiego, do dnia św. Elżbiety (19 listopada). Można z tego wnosić, że brakuje zakończenia źródła, które obejmowało zapewne koniec listopada i grudzień i mogło też zawierać informacje o autorze czy celu spisania. Nie jest to brak wywołany uszkodzeniem - poszyt ma jeszcze kilka stron, które z jakichś względów nie zostały zapisane. Specyficzne jest ograniczenie się, zapowiedziane zresztą w tytule, do jarmarków wielkopolskich i śląskich. Tylko nieliczne wzmianki wykraczają bowiem poza te ramy. Koncentruje się więc nasze źródło na ostatnim etapie handlu wołami na terenie Rzeczypospolitej oraz na pierwszym poza jej granicami ${ }^{19}$.

Poza kwestiami gospodarczymi publikowane źródło pozwala na badania dotyczące świadomości czasu i percepcji świąt kościelnych. Większość dat określanych jest za pomocą świąt Kościoła katolickiego obchodzonych na obszarze Rzeczypospolitej, ale zdarzają się wyjątki od tej reguty. Po pierwsze, jest to określanie dni patronami popularnymi w Kościele niemieckim - należałoby rozważyć, czy jest to efekt mechanicznego przetłumaczenia terminu jarmarku na język polski, czy świadome użycie, związane ze znajomością kultu i wynikłe z bliskiego sąsiedztwa. Po drugie, jest to oznaczenie daty za pomocą nazwy miesiąca i liczb określających dni miesiąca. Jest to o tyle intrygujące, że wydaje się stworzone przez samego autora źródła.

Trzecią zastanawiającą kwestią są przesunięcia dat jarmarków występujących w źródle względem dat przekazywanych przez przywileje - czy jest to kwestia rozpowszechnienia kultu poszczególnych świętych, czy faktycznie dany jarmark

\footnotetext{
${ }^{20}$ Matricularum Regni Poloniae summaria, wyd. T. Wierzbowski, t. 4/1, Warszawa 1910, nr 4697; tamże, t. 4/2, Warszawa 1912, nr 14435 (przywileje $z$ lat 1525 i 1526).
} 
został przeniesiony o kilka dni. Przykładem może być jarmark w Uniejowie, który według przywilejów ${ }^{20}$ miał się odbywać na św. Floriana (4 maja), zaś według naszego źródła miał miejsce w dzień świętych Filipa i Jakuba (1 maja). W tym wypad$\mathrm{ku}$ przeniesienie jarmarku byłoby o tyle zrozumiałe, że w późniejszym terminie mógł, choć nie musiał, kolidować z jarmarkiem w Kobylinie, rozpoczynającym się w dzień Wniebowstąpienia, który jako święto ruchome może przypaść już 2 maja. Dzięki wcześniejszemu rozpoczęciu jarmarku uniejowskiego kupcy mogli z dużym prawdopodobieństwem wziąć udział w obydwu.

W celu udostępnienia źródła badaczom publikujemy je in extenso. Tekst, spisany w języku polskim, datujemy na prawdopodobnie 2. poł. XVI w. ${ }^{21}$ Został on najpewniej wytworzony w granicach ówczesnego Królestwa Polskiego, a swoim zasięgiem obejmuje ziemie Wielkopolski i Śląska oraz pojedyncze miasta niemieckie. Wiele wskazuje na to, że jest odpisem albo niedokończoną kompilacją treści z innych dokumentów. Przyczyny nagłego urwania tekstu na 19 listopada, mimo wolnych kart 5v i 6, są nieznane. Raczej nie był on tworzony jako wprawka w pisaniu, ponieważ charakter pisma autora jest bardzo wyrobiony. Widać, że cały dokument spisany jest jedną ręką, staranne i praktycznie bez skreśleń.

Do wydania przyjęto zasady edytorskie proponowane przez Kazimierza Lepszego w Instrukcji uydawniczej dla źródet historycznych od XVI do potowy XIX wieku ${ }^{22}$, modyfikując je nieznacznie na potrzeby prezentowanego źródła. Pozostawiono niezmodernizowaną i nieujednoliconą pisownię nazw miejscowych (np. Koszmin i Kossmin) oraz świąt kościelnych, których błędnego zapisu często

\footnotetext{
${ }^{21}$ Jednoznacznymi datami post quem są wymienione wyżej przywileje dla Uniejowa, czyli początek 2. ćw. XVI w. Jednak zarówno cechy paleograficzne tekstu, jak i jego podobieństwo do instruktarza z 1584 r. pozwalają przesunąć datowanie o mniej więcej ćwierć wieku.

${ }^{22}$ Instrukcja wydawnicza dla źródet historycznych od XVI do połowy XIX wieku, red. K. Lepszy, Wrocław 1953.

${ }^{23}$ Chronologia polska, red. B. Włodarski, Warszawa 1957.

${ }^{24} \mathrm{H}$. Grotefend, Taschenbuch der Zeitrechnung des deutschen Mittelalters und der Neuzeit, Hannover 1971.

${ }^{25}$ Województwo sieradzkie i województwo tęczyckie w drugiej połowie XVI wieku, cz. 1-2, red. H. Rutkowski, oprac. K. Chłapowski i in., Warszawa 1998 (Atlas historyczny Polski. Mapy szczegótowe XVI wieku, 5).
}

nie poprawiamy ani dodatkowo nie oznaczamy. Układ chronologiczny tekstu został zachowany. Pominięto linie, które oddzielają w tekście oryginału kolejne zapiski.

W ustalaniu datacji świąt posłużyliśmy się Chronologia polskq i i Taschenbuch der Zeitrechnung ${ }^{24}$. Nazwy miejscowe zostały zidentyfikowane na podstawie literatury fachowej przedstawionej we wstępie historycznym, „Atlasie Fontium” (www.atlasfontium.pl), Atlasie historycznym Pol$s k 2^{25}$, Handbuch der historischen Stätten ${ }^{26}$ oraz Stowniku historyczno-geograficznym ziem polskich $w$ średniowieczu $u^{27}$ i Stowniku geograficznym Królestwa Polskiego i innych krajów stowiańskich ${ }^{28}$.

Zespołowi wydawniczemu zależało, aby tekst był czytelny i niezaciemniony nadmiarem aparatu krytycznego oraz by wiernie oddawał obraz źródła. Mamy nadzieję, że zachowanie nieujednoliconej i niezmodernizowanej pisowni nazw miejscowych oraz świąt umożliwi także analizę tego przekazu pod względem językoznawczym.

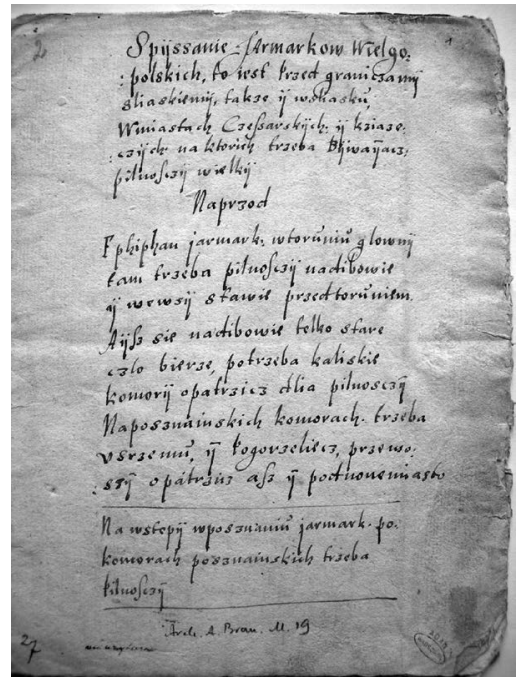

Ryc. 1. Strona tytułowa "Spisania jarmarków" (fot. A.P. Ortowska)

\footnotetext{
${ }^{26}$ H. Weczerka, Handbuch der historischen Stätten: Schlesien, Stuttgart 1977.

${ }^{27}$ Stownik historyczno-geograficzny ziem polskich w średniowieczu. Edycja elektroniczna, red. T. Jurek, oprac. inform. S. Prinke (http://www.slownik. ihpan.edu.pl/index.php, dostęp: 17 września 2015).

${ }^{28}$ Stownik geograficzny Królestwa Polskiego i innych krajów słowiańskich, wyd. F. Sulimierski, W. Walewski, Warszawa 1880-1914.
} 
Spis zaleceń na temat prawidtowego zachowania podczas obserwacji handlu wotami na jarmarkach i komorach celnych Wielkopolski

Or. Archiwum Gtówne Akt Dawnych, Zbiór Dokumentów Papierowych, nr 3780. Dokument papierowy o wymiarach $23 \times 33 \mathrm{~cm}$, luźna sktadka tworząca 6 kart, znak wodny w postaci korony ztaczonej z litera , W”.

Spisanie jarmarków wielgopolskich, to jest przed granicami sliaskiemi, także i w Sliasku, w miastach cesarskich i książęcych, na których trzeba bywająć pilności wielki.

Naprzód

Ephiphan[ia] [6 I] jarmark w Toruniu główny. Tam trzeba pilności na Dibowie ${ }^{1}$ i we wsi Stawie przed Toruniem. A iż się na Dibowie tylko stare cło bierze, potrzeba komory kaliskie opatrzyć dla pilności. Na posznainskich komorach trzeba w $S_{r z e m u}{ }^{2}$ i Pogorzeliecz ${ }^{3}$ przewozy opatrzyć, aż i pod Nowe Miasto ${ }^{4}$.

Na wstępie w Posznaniu jarmark po komorach posznainskich trzeba pilności.

[k. 1v] Na Srzodpostu [1 III-4 IV] we Wroczlawiu sliaskiem jarmark. Na kaliskie komory trzeba zajechać, do Wieliunia ${ }^{5}$, Bolieslawcza ${ }^{6}$, Ostrzessowa ${ }^{7}$, towary z Lublina idą i z Podliassą ${ }^{8}$.

Na S. Woycziech [23 IV] w Gnieznie jarmark główny. Po komorach trzeba tak posznainskich, jako i kaliskich pilności wielki.

Pro die Philipi Jakobi [1 V] w Unieiowie ${ }^{9}$ jarmark na woły. Tam trzeba być.

Pro Ascenssione Domini [30 IV-3 VI] w Kobilinie ${ }^{10}$ jarmark. Tam trzeba być.

Pro Pentecoste $[10 \mathrm{~V}-13 \mathrm{VI}]$ w Koszminie ${ }^{11}$ jarmark na woły. Tam trzeba być.

Pro festo Corpris Christi [21 V-24 VI] w Warczie ${ }^{12}$ jarmark na konie i woły. Tam trzeba być pilnie.

[k. 2r] Pro Joannis [24 VI] we Wroczlawiu sliaskiem jarmark. Na kaliskie komory zajechać trzeba, do Wielunia, Bolieslawcza, Ostrzessowa, towary z Lublina z Masuss ${ }^{13}$ przechodzą.

Pro Joannis w Posznaniu jarmark. Na komory posznainskie pilne oko trzeba mieć.

Pro Margarete [13 VII] jarmark w Gostiniu ${ }^{14}$ główny na woły. Tam trzeba pilnie się przypatrować na targowisku, a pisać, gdzie, kto i skąd woły kupować będzie. $Z$ tego Gostinia zajechać trzeba po komorach, począwszy Sulmierzycze ${ }^{15}, Z_{\text {duny }}{ }^{16}$, Jutrossyn ${ }^{17}$, Poniecz $^{18}$, Wschowa ${ }^{19}$, Kopanicza ${ }^{20}$, aż do Groicza ${ }^{21}$, Zbassynia ${ }^{22}$ dlia przeliczenia wołów.

Z tegoż jarmarku gostinskiego woły idą na jarmark pro Jacobi [25 VII] do Gory Sliasky²3, miasta cesarskiego. Tam trzeba dojrzeć pilnie, jako wielie do targu wołów przypuszczą i co zaś do paszy puszczą $\mathrm{z}$ targowiska albo coby nazad, nieprzedawszy, gnały.

[k. 2v] Z Sokalia ${ }^{24}$ do Czerwastu ${ }^{25}$ woły przechodzą na Grodziecz i Zbassyn die 1/2/3/4 augusti [1-4 VIII]. Tam trzeba dlia pilnego liczenia zajechać.

Pro Laurenti [10 VIII] w Kossmynie jarmark główny. Tam trzeba na targowisku pilnie przypatrować i pisać, skąd i kto wielie wołów kupi. Stamtąd trzeba zajechać po komorach, począwszy Sulmierzycze, [k. 3r] Zduny, Jutrossyn, Poniecz, Wschowa, Kopanicza, aż do Groicza i Zbassynia dlia liczenia wołów. Z tego jarmarku kossminskiego idą woły na jarmark pro Asumptione Mariae [15 VIII] do

\footnotetext{
${ }^{1}$ Dybów, zamek na lewym brzegu Wisty, naprzeciw Torunia. ${ }^{2}$ Śrem, miasto nad Wartą. ${ }^{3}$ Pogorzelica, wieś nad Wartą. ${ }^{4}$ Nowe Miasto nad Wartą, miasto. ${ }^{5}$ Wieluń, miasto. ${ }^{6}$ Bolesławiec, miasto nad Bobrem. ${ }^{7}$ Ostrzeszów, miasto. ${ }^{8}$ Prawdopodobnie chodzi tu 0 Podlasie. ${ }^{9}$ Uniejów, miasto nad Wartą. ${ }^{10}$ Kobylin, miasto. ${ }^{11}$ Koźmin, miasto nad Orlą. ${ }^{12}$ Warta, miasto nad Wartą. ${ }^{13}$ Być może chodzi tu 0 Mazury. ${ }^{14}$ Gostyń, miasto. ${ }^{15}$ Sulmierzyce, miasto.

${ }^{16}$ Zduny, miasto. ${ }^{17}$ Jutrosin, miasto nad Orlą. ${ }^{18}$ Poniec, miasto. ${ }^{19}$ Wschowa, miasto. ${ }^{20}$ Kopanica, miasto. ${ }^{21}$ Brójce, wieś. ${ }^{22}$ Zbąszyń, miasto nad

Obrą. ${ }^{23}$ Góra, miasto. ${ }^{24}$ Sokal, miasto nad Bugiem, $50 \mathrm{~km}$ na południowy wschód od Hrubieszowa (obecnie na Ukrainie). ${ }^{25}$ Miejsce niezidentyfikowane.
} 
Glogowa, miasta cesarskiego. Tam trzeba pilnie przypatrować, jako wielie do targu przypuszczą i jako wielie zaś do paszy na noc puszczą albo coby zaś ku domowi nazad puszczano.

$\mathrm{Z}$ jarmarku jaroslawskiego ${ }^{26}$, który bywa pro Asumptione Mariae, idą woły do Lipska ${ }^{27}$, Brzegu ${ }^{28}$, Bugstetu $^{29}$. Tem wołom trzeba zajeżdżać po granicach i o nich się z pilnością pytać.

[k. 3v] Pro Bartolomeo [24 VIII] jarmark w Iaroczynie ${ }^{30}$ główny na woły. Tam trzeba pilnie upatrować, jako wielie, skąd i kto wołów kupi pisać. Stamtąd po komorach zajechać, począwszy Sulmierzycze, Zduny, Jutrossyn, Poniecz, Wschowa, Kopanicza, aż do Groicza, Zbassynia dlia liczenia wołów.

$\mathrm{Z}$ tego jarmarku idą woły pro decolatione Joannis [29 VIII] na jarmark do Wyna ${ }^{31}$, miasta ksiązęcia brzeskiego. Tam trzeba pilności, jako wielie wołów do targu przypuszczą.

Pro festo Matey [21 IX] w Kobilinie jarmark główny na woły. Tam trzeba pilnie upatrować, a pisać, jako wielie i kto, a skąd wołów kupi. [k. 4r] Stamtąd zajechać trzeba po komorach, począwszy Sulmierzycze, Zduny, Jutrossyn, Poniecz, Wschowa, Kopanicza, aż do Groicza i Zbassynia, dlia liczenia wołów. Z tego jarmarku woły idą pro Bruchaldi $[11 \mathrm{X}]$ na jarmark do Góry Sliasky, miasta cesarskiego. Tam trzeba pilne oko mieć, jako wielie do targu przypuszczą i coby zaś nazad gnały do paszy. Pro Michaeli [29 IX] w Posznaniu jarmark. Do Koczkowa ${ }^{32}$ woły idą z Russy. Na Grodziecz i Zbassyn zajechać trzeba dlia liczenia pilnego.

[k. 4v] Pro festo Hedvigis [15 X] w Nowym Miesczie jarmark. Tam trzeba na targowisku pilnie patrzyć i pisać, skąd i kto wielie wołów kupi. Z tego jarmarku trzeba zajechać po komorach, począwszy Sulmierzycze, Zduny, Jutrossyn, Poniecz, Wschowa, Kopanicza, aż do Groicza, Zbassynia dlia liczenia wołów.

Pro Galli Nundinis [16 X] w Swidniczy jarmark. Na kaliskie komory zajechać trzeba, dlia pilności, gdi woły przechodzą.

Pro festo Simonis Judae [28 X] woły idą z Nowego Miasta na jarmark do Rudna ${ }^{33}$, miasta książęcia brzeskiego. Tam trzeba być i pilności wielki przyłożyć.

[k. 5r] Pro festo Martini [11 XI] w Iaroczynie jarmark. Tam trzeba pilnować na targowisku, jako wielie wołów kto i skąd kupi. Stamtąd zajechać trzeba po komorach, począwszy Sulmierzicze, Zduny, Jutrossin, Poniecz, Wschowa, Kopanicza, aż do Groicza, Zbassynia dlia liczenia wołów.

Pro Helizabet [19 XI] we Wroczlawiu sliaskiem jarmark. Na kaliskie komory zajechać trzeba do Wieliunia, Bolieslawcza, Ostrzessowa. Towary przechodzą z Masus i od Lublina.

\footnotetext{
${ }^{26}$ Jarosław, miasto nad Sanem. ${ }^{27}$ Miasto w Saksonii. ${ }^{28}$ Brzeg, miasto nad Odrą. ${ }^{29}$ Buttstädt, miasto w Turyngii, 15 km na północ od Weimaru. ${ }^{30}$ Jarocin, miasto. ${ }^{31}$ Prawdopodobnie Wińsko, miasto, obecnie wieś $15 \mathrm{~km}$ na północ od Wołowa. ${ }^{32}$ Miejsce niezidentyfikowane. Być może chodzi o Kożuchów, miasto ok. 25 km na południe od Zielonej Góry. ${ }^{33}$ Rudna, miasto, obecnie wieś.
} 


\section{Bibliografia}

„Atlas Fontium” (http://atlasfontium.pl, dostęp: 17 września 2015).

Bartoszewicz H., Drogi handlowe ziemi chetmińskiej, „Miscellanea Historico-Archivistica”, 6, 1996, s. 43-64.

Baszanowski J., $Z$ dziejów handlu polskiego w XVIXVIII w. Handel wotami, Gdańsk 1977.

Chronologia polska, red. B. Włodarski, Warszawa 1957.

Grotefend H., Taschenbuch der Zeitrechnung des deutschen Mittelalters und der Neuzeit, Hannover 1971.

Instrukcja wydawnicza dla źródet historycznych od XVI do potowy XIX wieku, red. K. Lepszy, Wrocław 1953.

Mączak A., Heinz Wiese, Johann Bölts, „Rinderhandel und Rinderhaltung im nordwesteuropäischen Küstengebiet vom 15. bis zum 19. Jahrhundert”, „Quellen und Forschungen zur Agrargeschichte" herausgegeben von Friedrich Lütge, Günther Franz und Wilhelm Abel, t. XIV, Gustav Fischer Verlag. Stuttgart 1966, s. 272, „Przegląd Historyczny”, 60 (4), 1969, s. $731-735$.

Rybarski R., Handel i polityka handlowa Polski w XVI stuleciu, t. 1: Rozwój handlu polityki handlowej, Poznań 1928.

Samsonowicz H., Handel na pograniczu polsko-ślaskim w swietle danych komory celnej $w$ Częstochowie z 1584 r., „Kwartalnik historyczny”, 99 (4), 1992, s. $3-16$.

Samsonowicz H., Jarmarki $w$ Polsce na tle sytuacji gospodarczej $w$ Europie $w X V-X V I$ wieku, w: Europa-
Stowiańszczyzna - Polska. Studia ku uczczeniu profesora Kazimierza Tymienieckiego, wyd. J. Bardach i in., Poznań 1970, s. 523-532.

Samsonowicz H., Przemiany osi drożnych $w$ Polsce późnego średniowiecza, „Przegląd historyczny”, 64, 1973 , s. 697-716.

Stownik geograficzny Królestwa Polskiego i innych krajów stowiañskich, wyd. F. Sulimierski, W. Walewski, Warszawa 1880-1914.

Stownik historyczno-geograficzny ziem polskich $w$ średniowieczu. Edycja elektroniczna, red. T. Jurek, oprac. informatyczne S. Prinke (http://www.slownik.ihpan.edu.pl/index.php, dostęp: 17 września 2015).

Stromer W. von, Wildwest in Europa: Der transkontinentale Ochsenhandel in der frühen Neuzeit, „Kultur und Technik", 2, 1979, s. 36-43.

Topolski J., Rola Gniezna w handlu europejskim od $X V$ do XVII wieku, „Studia i Materiały do Dziejów Wielkopolski i Pomorza”, 7 (2), 1962, s. 5-78.

Weczerka H., Handbuch der historischen Stätten: Schlesien, Stuttgart 1977.

Województwo sieradzkie $i$ województwo tęczyckie $w$ drugiej potowie XVI wieku, cz. 1-2, red. H. Rutkowski, oprac. K. Chłapowski i in., Warszawa 1998 (Atlas historyczny Polski. Mapy szczegótowe XVI wieku, 5).

Wolański M., Zwiazki handlowe Ślaska z Rzeczapospolita w XVII wieku, Wrocław 1961.

\section{The Trade in 0xen on the Territory of the Greater Poland and Silesia in the Light of the $16^{\text {th }}$ Century Description of Annual Fairs and Toll Houses}

\section{Summary}

The trade in oxen, along with the trade in grain, was one of two most important branches of Polish export trade in the $16^{\text {th }} \mathrm{c}$. Both merchandises were produced in the Polish-Lithuanian kingdom and were exported to Western Europe. However, the specific trade routes differ due to the different properties of these goods. While grain was a typical bulk good, the transport of which required cheap means of transportation, it was exported via sea and delivered to harbours through rivers, the trade routes of oxen ran orthogonal to those of grain (i.e. parallel to the sea), for the simple reason that oxen can move on their own. Furthermore, the final destinations of these goods lay in the annual fairs in Silesia and Saxony which were located far from the Baltic Sea. 
These trade routes typically began in the south-east, around the Moldavian regions, and crossed the country towards the north-west.

Analysing the history of these trade relations is uncommonly challenging since most of the official sources were destroyed during World War II. The source investigated in the present text was transmitted through a private archive (it belonged to the Branicki family) and thus, it survives to this day.

The text in question is written in a paper booklet of only six pages, giving no information on the time and place of its origin, or about the author. It is not even clear whether the writer was the actual author or whether the text is a copy of another manuscript. The aim of the text is to explain the proper behaviour for the observant of the oxen trade. The intended reader was to be interested in trade due to his occupation such as a young merchant or a toll keeper. The manuscript details the steps necessary or helpful for dealing with the annual fairs and toll houses of Greater Poland, explaining how to retrace the path of the oxen, e.g. looking out for how often how many oxen were given water. The text assumes a chronological structure, i.e. it starts in January and abruptly ends in November. The reasons why the second half of November and December are missing are not clear - several pages are left blank.

To the researches, these descriptions provide a unique insight into the functionalities of the annual fairs in Greater Poland of those times, and the mechanisms of their trade.

Słowa kluczowe : handel, jarmarki, woły, Wielkopolska, Śląsk, Lipsk, Saksonia, XVI wiek

Keyw ords: trade, annual fairs, oxen, Greater Poland, Silesia, Leipzig, Saxony, $16^{\text {th }}$ century

dr Anna Paulina Orłowska - Instytut Historii im. Tadeusza Manteuffla

Polskiej Akademii Nauk. Zainteresowania badawcze: historia gospodarcza

późnego średniowiecza i wczesnej nowożytności, historia handlu, historia miast, edycja źródeł historycznych i jej techniki

(e-mail: anna.p.orlowska@gmail.com)

dr Bartosz Nowożycki - Naczelna Dyrekcja Archiwów Państwowych.

Zainteresowania badawcze: historia najnowsza Polski (głównie lata 1939-1989),

teoria i metodyka archiwalna (kraje anglosaskie)

(e-mail: bnowozycki@tlen.pl)

dr Grzegorz Pac - Instytut Historyczny Uniwersytetu Warszawskiego.

Zainteresowania badawcze: wcześniejsze średniowiecze polskie i powszechne: rola społeczna kobiet, queenship, ideologia władzy, hagiografia i kult świętych, kult Marii Panny, monastycyzm

(e-mail: gl.pac@uw.edu.pl) 